\title{
Improve Students' Numeracy Skills Using Learning Videos
}

\section{Putu Andre Apriliawan 1*, Desak Putu Parmiti2}

1,2 Universitas Pendidikan Ganesha, Singaraja, Indonesia

\section{ART I CLE IN F O}

\section{Article history:}

Received March 03, 2021

Revised March 09, 2021

Accepted April 27, 2021

Available online May 25, 2021

Kata Kunci:

Pengembangan, Video

Pembelajaran, Berhitung

Keywords:

Development, Instructional Videos, Counting

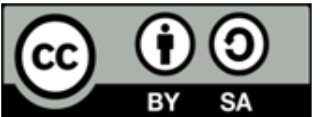

This is an open access article under the CC BY-SA license.

Copyright () 2021 by Author. Published by Universitas Pendidikan Ganesha.

\begin{abstract}
A B S T R A K
Pandemi Covid-19 mengharuskan siswa sekolah dasar untuk melaksanakan pembelajaran daring, tetapi banyak kendala pada Fpembelajaran daring, salah satunya pada proses pembelajaran matematika. Penelitian ini bertujuan untuk menciptakan video pembelajaran berhitung dan mengembangkan video pembelajaran berhitung untuk siswa sekolah dasar yang teruji validitasnya yang menggunakan model pengembangan ADDIE. Subjek pada penelitian ini adalah dua ahli media, dua ahli materi, dan dua praktisi. Data yang dikumpulkan adalah data kualitatif dan kuantitatif. Metode pengumpulan data yang digunakan adalah metode kuesioner dan mengukur validitas video pembelajaran berhitung menggunakan instrumen rating scale. Penelitian ini menghasilkan video pembelajaran berhitung yang sudah teruji validitasnya dengan skor rata-rata validasi secara keseluruhan untuk video pembelajaran adalah 4,78 dan skor ratarata validasi materi adalah 4,87. Hal ini berarti video pembelajaran berhitung yang dikembangkan tergolong sangat baik. Oleh karena itu, pembelajaran berhitung untuk siswa kelas I sekolah dasar dinyatakan valid dan layak untuk dikembangkan serta dibelajarakan kepada siswa.
\end{abstract}

\begin{abstract}
A B S T R A C T
The Covid-19 pandemic requires elementary school students to carry out online learning, but there are many obstacles to online learning, one of which is the mathematics learning process. This study aims to create a learning video to count and develop a learning video to count for elementary school students whose validity has been tested using the ADDIE development model. The subjects in this study were two media experts, two material experts, and two practitioners. The data collected are qualitative and quantitative. The data collection method used is a questionnaire method and measures the validity of the video learning counting using a rating scale instrument. This research produces a numeracy learning video tested for validity with an overall average validation score for learning videos is 4.78, and the average material validation score is 4.87. It means that the counting learning videos developed are classified as very good. Therefore, numeracy learning for first-grade elementary school students is valid and feasible to develop and taught to students.
\end{abstract}

\section{INTRODUCTION}

The pandemic period has caused a shift in learning from face-to-face learning to online learning. This online learning is the most effective solution for carrying out the learning process because students can connect with their learning resources remotely but still communicate with each other and interact between teachers and teachers, teachers with students, and students with students (Nengrum et al., 2021; Sadikin \& Hamidah, 2020). Online learning causes a change in traditional methods to the digital era so that learning is not limited by space and time (Dhir et al., 2021; Krishnan et al., 2021; Park \& Kang, 2021; Prihatin, 2017). In the online learning process, teachers are expected to create active, creative learning and increase student motivation in the learning process to achieve the learning objectives set while improving student personality (Manta \& Enache, 2020). Online learning is a distinct advantage, especially for students who can practice their abilities to be more active in building knowledge (Villegas et al., 2020). One component of the all-encompassing lesson in mathematics. Learning mathematics in schools is one component of education that develops the ability and skills to apply mathematics and develops problemsolving skills (Setiawan \& Harta, 2014). In learning mathematics, there are aspects, one of which is counting. Counting activities for early childhood or elementary school are also referred to as activities of mentioning a number sequence or knowing the number of an object (Malapata \& Wijayanigsih, 2019; Mardika, 2019). However, learning mathematics is considered boring, difficult, and difficult for students to understand (Aunio et al., 2021; Battistin et al., 2017; Hakim \& Windayana, 2016; Komariah \& Sundayana, 2017; Kurniawan \& Rivaldi, 2021). Learning mathematics is considered as boring, difficult, and difficult to understand for students due to the implementation of mathematics learning that is less innovative and 
creative, abstract mathematics learning, and the selection of learning methods that are not appropriate (Hakim \& Windayana, 2016; Komariah \& Sundayana, 2017).

However, during the Covid-19 pandemic with an online learning system, mathematics learning experienced a fairly complicated renewal, especially for the productivity of students studying at home who needed time to adapt (Dewi, 2020). Innovation is needed in learning mathematics so that mathematics learning during the Covid-19 pandemic becomes more effective (Hakim \& Windayana, 2016; Verdeflor \& Pacadaljen, 2021). Learning mathematics during the Covid-19 pandemic is considered less effective because of the many obstacles that occur due to the internet network that is difficult to reach. Students are left behind in learning and have difficulty understanding learning materials (Kusumaningrum \& Wijayanto, 2020). The sudden use of the learning system due to the Covid-19 pandemic has also caused a decrease in student interest in learning (Annur, 2020). In the ability to count, it takes attention to the stage of cognitive development in children. Children's cognitive development must start from fun, innovative, and creative learning so that students can explore and develop their cognitive abilities (Yatini et al., 2013). Based on a questionnaire from November, $6^{\text {th }} 2020$ to November, $10^{\text {th }} 2020$ to first-grade teachers at elementary schools in Gugus I, Kecamatan Buleleng, only 37.5\% of teachers used learning videos online process $12.5 \%$ of teachers made learning videos. Themselves to teach children to count during the Covid-19 pandemic. After analyzing the numeracy learning videos used in online learning, the learning materials in the learning videos used still lack depth and width and limited examples and demonstrations applied in the learning videos. It is because most of the first grade teachers are not fluent in using gadgets. If during the implementation of online learning students still receive learning with learning media that does not fully explain the learning material to students, then students will not be helped in changing abstract mathematical concepts into concrete. Learning mathematics will also remain boring, difficult, and difficult to understand if you continue to use inappropriate learning media. If this continues, the quality of learning will not improve (Komariah \& Sundayana, 2017).

One of the technology-based solutions currently available and the easiest to obtain is learning media. Learning media that can be used in online learning are learning videos (Mustaqim \& Kurniawan, 2018; Yunita \& Wijayanti, 2017). Learning video media is a set of components or media that can display images and sound simultaneously (Kurniawan, 2016). Learning video is one type of media that prioritizes the power of sound and images (Nurdin et al., 2019; Pamungkas et al., 2018). Through learning videos, the material is delivered in the form of a complete story. This learning video has several advantages, including the material presented can be received equally by students. It is good at explaining a process, overcomes space and time limitations, is more realistic, can be repeated, and stopped as needed, affect student attitudes (D. C. Kurniawan et al., 2018). But the transition of learning, from what was originally face-toface to online learning, gave rise to many effects for children, considering this happened suddenly without prior preparation (Rigianti, 2020). The solutions offered have been implemented through research. It was found that the level of validation of the developed numeracy learning media was classified as good. It was seen from the results of the t-test. Students scored above 70 (91.67\%) using compact arithmetic media, which were classified as complete (Syamsuddin \& Lukman, 2019). Other research stated that the learning media developed is feasible to use (Purwanti, 2015). In addition, learning videos could solve problems in developing children's early numeracy skills (Yuliani et al., 2017). It can be seen from the first assessment using learning videos by $65.43 \%$, and in the second learning, it increases to $84.18 \%$. It is line with some studies that stated the learning video developed is feasible to use (Batubara \& Ariani, 2016; Gayathri et al., 2021; Saiboon et al., 2021). Developing this learning video is limited to counting material, especially comparing concrete objects to find out which objects have a greater score, so developing other materials requires adjustments.

Based on research done previously, learning media can improve the quality of learning and is effectively applied in learning activities. However, there are no learning media that can be used in various learning situations and efficiently teach early arithmetic. Thus, a numeracy learning video was developed for first-grade elementary school students expected to be an effective, efficient, and useful learning media in various learning situations to teach children to count early. The advantages of counting learning videos are that they can improve students' numeracy skills, packaged using material comparing concrete objects and using interesting methods, and can be used anywhere and anytime. Learning videos can be repeated if students have not achieved understanding. It can illustrate concepts that are abstract with interesting and meaningful animations. It can be accessed through social media with the youtube application via a device or laptop. It displays practice questions to hone students' numeracy skills. It gives assignments as a follow-up to learning at the end of the video and provides learning motivation to students. The use of YouTube media is very appropriate to distribute numeracy learning videos because students like social media and use it to transfer information. Learning videos as learning media is very easy, fast, and precise (Ramprathap, 2021). 
This research aims to create a learning video to count for elementary school students and develop a learning video to count for elementary school students whose validity has been tested. In addition, this study aims to develop a numeracy learning video process for first-grade elementary school students so that the learning video development process is structured according to the model used and is feasible to use. With this research, it is hoped that first-grade elementary school students will learn to start counting in a fun, effective, practical way and eliminate the notion of boring mathematics learning. The use of learning video media is to attract students' desire and motivation to learn.

\section{METHOD}

The type of research used is development research using the ADDIE development model. The ADDIE development model choosed because it is systematic and can be used in various conditions, making it possible to use this model to date (Mustaqim \& Kurniawan, 2018). The five stages of the ADDIE model are analysis, design, development, implementation, and evaluation (Cahyadi, 2019; Tegeh \& Kirna, 2013). The ADDIE model choosed because it has advantages. After all, the ADDIE model aims to develop and produce a product (Purwani et al., 2019). The analysis phase was carried out by analyzing the needs, curriculum, student characteristics, and media. The design phase begins with designing the concept in the developed numeracy learning video. Then the idea is consulted with the supervisor to get input, suggestions, and revisions. After the learning video design has been repaired and has received approval from the supervisor, it will proceed to the next stage, the development stage. The development stage was carried out after the numeracy learning video is following the supervisor's design. Furthermore, the data from the assessment results were analyzed and revised based on the input and suggestions of the assessment team.

The subjects of this study were tested by two media experts, two materials experts, and two practitioners. This study used descriptive qualitative data analysis methods and quantitative descriptive data analysis. The qualitative descriptive analysis method was used to process data from inputs, suggestions, and criticisms from the results of expert reviews of numeracy learning videos developed through media assessment sheets in the form of questionnaires. The quantitative descriptive analysis method is used to generate data in the form of numbers obtained from giving a video validation assessment sheet for counting lessons for first-grade elementary school students that has been developed for teachers as practitioners and lecturers as experts. This research method was a questionnaire. Questionnaires are data collection by communicating online or offline with data sources. In this study, questionnaires were distributed in SD Gugus I, Kecamatan Buleleng, to determine the media needs in online learning. The results of the questionnaire are needed to determine the validity of the developed media. This method is used to get the average score from experts related to media developed using the mean formula (Agung, 2016). The results of the content validity test are the quality and feasibility of an instrument. Two judges tested content validity. This content validity used the Gregory formula. The validation of the instrument that two judges have assessed is 21 items which get a very relevant score by the judges. Based on this, the numeracy learning video assessment is valid with a very high level of content validity.

This study used a rating scale instrument. The rating scale is a research method in the form of numbers based on a scale from low to high (Ilhami \& Rimantho, 2017). The rating scale is a research method in the form of numbers based on a scale from low to high. The validation sheet instrument refers to developing learning videos that include six aspects that need to be considered: visual, audio, typography, presentation, material, and language (Arsyad, 2014). The effort to ensure the instrument's validity is to make a grid in consultation with the supervisor. The instrument grid for the learning video validation sheet is presented in Table 1 , Table 2 , and Table 3.

Table 1. Instruments for validation of media expert learning videos

\begin{tabular}{|c|c|c|c|}
\hline No. & Aspect & Indicator & Number \\
\hline \multirow[t]{5}{*}{1} & Visual & a. Image clarity & 1 \\
\hline & & b. Shooting Suitability & 2 \\
\hline & & c. Attractive colors, backgrounds, images, and animations & 3 \\
\hline & & d. Image motion speed & 4 \\
\hline & & e. Lighting accuracy & 5 \\
\hline \multirow[t]{3}{*}{2} & Audio & a. Voice clarity & 6 \\
\hline & & b. Sound rhythm & 7 \\
\hline & & c. Music compatibility & 8 \\
\hline
\end{tabular}




\begin{tabular}{cllcc}
\hline No. & Aspect & Indicator & Number \\
\hline 3 & Typography & a. Text type selection & & 9 \\
& & b. Text size accuracy & 10 & 11 \\
\multirow{2}{*}{4} & \multirow{2}{*}{ Presentation } & a. Interesting & 12 \\
& & b. Time duration & 13 \\
\hline Total & & c. Clarity of storyline & $\mathbf{1 3}$ \\
\hline
\end{tabular}

Table 2. Instruments for validation of material expert learning videos

\begin{tabular}{cllc}
\hline No. & \multicolumn{1}{c}{ Aspect } & \multicolumn{1}{c}{ Indicator } & Number \\
\hline 1 & Material & a. Clarity of learning materials & 1 \\
& & b. Suitability of learning videos with learning objectives & 2 \\
& c. The Suitability of learning videos with learning materials & 3 \\
2 & \multirow{2}{*}{ language } & d. The accuracy of the distribution and coherence of the material & 4 \\
& & a. Language compatibility with Indonesian rules & 5 \\
& b. The sentences used are easy to understand & 6 & 7 \\
& c. The communicative nature of the language used & 8 \\
\hline Total & d. Language level with student's cognitive & $\mathbf{8}$ \\
\hline
\end{tabular}

Table 3. Practitioner validation instrument

\begin{tabular}{|c|c|c|c|}
\hline No & Aspect & Indicator & Number \\
\hline \multirow[t]{5}{*}{1} & Visual & a. Image clarity & 1 \\
\hline & & b. Shooting Suitability & 2 \\
\hline & & c. Attractive colors, backgrounds, images, and animations & 3 \\
\hline & & d. Image motion speed & 4 \\
\hline & & e. Lighting accuracy & 5 \\
\hline \multirow[t]{3}{*}{2} & Audio & a. Voice clarity & 6 \\
\hline & & b. Sound rhythm & 7 \\
\hline & & c. Music compatibility & 8 \\
\hline \multirow[t]{2}{*}{3} & Typography & a. Text type selection & 9 \\
\hline & & b. Text size accuracy & 10 \\
\hline \multirow[t]{4}{*}{4} & Material & a. Clarity of learning materials & 11 \\
\hline & & b. Suitability of learning videos with learning objectives & 12 \\
\hline & & c. The Suitability of learning videos with learning materials & 13 \\
\hline & & d. The accuracy of the distribution and coherence of the material & 14 \\
\hline \multirow[t]{4}{*}{5} & language & a. Language compatibility with Indonesian rules & 15 \\
\hline & & b. The sentences used are easy to understand & 16 \\
\hline & & c. The communicative nature of the language used & 17 \\
\hline & & d. Language level with student's cognitive & 18 \\
\hline \multirow[t]{3}{*}{6} & Cohesiveness & a. Have attraction & 19 \\
\hline & & b. Time duration & 20 \\
\hline & & c. Clarity of the storyline & 21 \\
\hline Total & & & 21 \\
\hline
\end{tabular}

\section{RESULT AND DISCUSSION}

\section{Result}

\section{Analysis Stage}

The first stage is the analysis stage. At this stage, several analyses were carried out, : an analysis of student characteristics was carried out to analyze the level of student knowledge used as an illustration in the development of learning videos according to the characteristics of first-grade elementary school students. Based on the analysis results, it was found that only $12.5 \%$ of teachers used self-made learning videos. $75 \%$ of arithmetic learning videos for first graders were still difficult to find, for example, limited examples available in sources such as youtube, lack of supporting images, and explanations that were too short. The curriculum analysis following the demands of competence to find out the material to be 
developed. Curriculum analysis was carried out by analyzing core competencies, basic competencies, and indicators in teacher and student books as a reference in developing media. A needs analysis was carried out to determine the needs of teachers and students when carrying out online learning by distributing questionnaires to teachers and first graders of elementary school about counting learning materials and the media used. Media analysis was carried out to collect information related to the criteria for a good learning video to be used as a reference. The analysis stage that has been carried out shows that numeracy learning videos made directly by first-grade elementary school teachers during online learning are still lacking. In addition, the transition from offline to online learning makes teachers still adapt to carry out maximum learning due to the limited use of learning videos, so students still have difficulty learning online. Therefore, it is necessary to develop numeracy learning videos for first-grade elementary school students.

\section{Design Stage}

The second stage designs. At this stage, the design of the developed learning video was carried out. This stage begins with making a storyline and determining the material to be developed. It is based on the results of the analysis that has been carried out in the field. The material chosen is numeracy. Then, a learning video design was prepared. The designs made are material design and media design. The material design is arranged according to the main objective, developing material through learning videos. In the media design, a video was made using the Kinemaster application. The ratio size of the learning video is $16: 9$, and the resolution is 720 . In addition, the techniques for making learning videos are designed with the support of images or animations according to the material discussed. After the design is complete, the next step is to provide guidance or consultation with the supervisor to obtain input and suggestions to improve the design. After the improvement results are approved, the research continues to the next stage, development.

Table 4. The design of the video storyline for counting lessons for first-grade elementary school students

\begin{tabular}{|c|c|c|c|c|c|}
\hline NO & PART & Content & MUSIC & SCENE & DESCRIPTION \\
\hline \multirow[t]{3}{*}{1} & Opening & Intro & $\begin{array}{l}\text { Uplifting } \\
\text { music }\end{array}$ & $\begin{array}{l}\text { Animated Text: } \\
\text { a. Personal identity } \\
\text { b. Title } \\
\text { a. c. Learning } \\
\quad \text { objectives }\end{array}$ & $\begin{array}{l}\text { Video Type: Animated text from } \\
\text { the Kine Master app. } \\
\text { Duration: } \pm 20 \text { seconds }\end{array}$ \\
\hline & & greet students & $\begin{array}{l}\text { soft } \\
\text { flowing }\end{array}$ & $\begin{array}{l}\text { Greet students with } \\
\text { a classroom picture } \\
\text { background. }\end{array}$ & $\begin{array}{l}\text { Shot Type: Medium } \\
\text { Equipment: green screen, tripod, } \\
\text { microphone, and camera phone } \\
\text { Duration: } \pm 20 \text { seconds }\end{array}$ \\
\hline & & $\begin{array}{l}\text { Associating } \\
\text { the material } \\
\text { with the } \\
\text { surrounding } \\
\text { environment }\end{array}$ & $\begin{array}{l}\text { soft } \\
\text { flowing }\end{array}$ & $\begin{array}{l}\text { The narrator stands } \\
\text { in front of the } \\
\text { camera, with a } \\
\text { classroom image in } \\
\text { the background. }\end{array}$ & $\begin{array}{l}\text { Shot Type: Medium } \\
\text { Equipment: greenscreen, tripod, } \\
\text { microphone, and camera phone } \\
\text { Duration: } \pm 45 \text { seconds }\end{array}$ \\
\hline \multirow[t]{3}{*}{2} & Core & $\begin{array}{l}\text { Give students } \\
\text { problems }\end{array}$ & $\begin{array}{l}\text { soft } \\
\text { flowing }\end{array}$ & $\begin{array}{l}\text { The narrator stands } \\
\text { in front of the } \\
\text { camera with a } \\
\text { blackboard } \\
\text { background and } \\
\text { shows the concrete } \\
\text { object compared. }\end{array}$ & $\begin{array}{l}\text { Shot Type: Medium } \\
\text { Equipment: greenscreen, tripod, } \\
\text { microphone, and camera phone } \\
\text { Duration: } \pm 8 \text { minutes }\end{array}$ \\
\hline & & $\begin{array}{l}\text { Explaining the } \\
\text { material }\end{array}$ & $\begin{array}{l}\text { soft } \\
\text { flowing }\end{array}$ & $\begin{array}{l}\text { The narrator stands } \\
\text { in front of the } \\
\text { camera, with a } \\
\text { classroom image in } \\
\text { the background. }\end{array}$ & $\begin{array}{l}\text { Shot Type: Medium } \\
\text { Equipment: tripod, microphone, } \\
\text { and camera phone } \\
\text { Duration: } \pm 50 \text { seconds }\end{array}$ \\
\hline & & $\begin{array}{l}\text { Summing up } \\
\text { the problems } \\
\text { already } \\
\text { discussed }\end{array}$ & $\begin{array}{l}\text { soft } \\
\text { flowing }\end{array}$ & $\begin{array}{l}\text { The narrator stands } \\
\text { in front of the } \\
\text { camera, showing a } \\
\text { line of numbers }\end{array}$ & $\begin{array}{l}\text { Shot Type: Medium } \\
\text { Equipment: microphone and Kine } \\
\text { Master app } \\
\text { Duration: } \pm 2 \text { minutes }\end{array}$ \\
\hline
\end{tabular}




\begin{tabular}{|c|c|c|c|c|c|}
\hline NO & PART & Content & MUSIC & SCENE & DESCRIPTION \\
\hline \multirow[t]{4}{*}{3} & Closing & $\begin{array}{l}\text { Summing up } \\
\text { the overall } \\
\text { material and } \\
\text { answer the } \\
\text { problems } \\
\text { given }\end{array}$ & $\begin{array}{l}\text { soft } \\
\text { flowing }\end{array}$ & $\begin{array}{l}\text { Narator berdiri di } \\
\text { depan kamera, } \\
\text { menyimpulkan hasil } \\
\text { pembahasan } \\
\text { dengan latar ruang } \\
\text { kelas }\end{array}$ & $\begin{array}{l}\text { Shot Type: Medium } \\
\text { Equipment: greenscreen, tripod, } \\
\text { microphone, and camera phone } \\
\text { Duration: } \pm 1 \text { minute }\end{array}$ \\
\hline & & $\begin{array}{l}\text { Provide } \\
\text { exercises as a } \\
\text { follow-up } \\
\text { study }\end{array}$ & $\begin{array}{l}\text { soft } \\
\text { flowing }\end{array}$ & $\begin{array}{l}\text { The narrator stands } \\
\text { in front of the } \\
\text { camera, delivering } \\
\text { with the } \\
\text { background of the } \\
\text { classroom. }\end{array}$ & $\begin{array}{l}\text { Shot Type: Medium } \\
\text { Equipment: greenscreen, tripod, } \\
\text { microphone, and camera phone } \\
\text { Duration: } \pm 1 \text { minute }\end{array}$ \\
\hline & & $\begin{array}{l}\text { The video } \\
\text { closes with } \\
\text { greetings and } \\
\text { thanks }\end{array}$ & $\begin{array}{l}\text { soft } \\
\text { flowing }\end{array}$ & $\begin{array}{l}\text { The narrator stands } \\
\text { in front of the } \\
\text { camera, says hello } \\
\text { and thank you. }\end{array}$ & $\begin{array}{l}\text { Shot Type: Medium } \\
\text { Equipment: greenscreen, tripod, } \\
\text { microphone, and camera phone } \\
\text { Duration: } \pm 30 \text { seconds }\end{array}$ \\
\hline & & Outtro & $\begin{array}{l}\text { Uplifting } \\
\text { Music }\end{array}$ & $\begin{array}{l}\text { Animated Text: } \\
\text { a. Image link } \\
\text { a. b. Video link }\end{array}$ & $\begin{array}{l}\text { Video Type: Animated Text from } \\
\text { the Kine Master app. } \\
\text { Duration: } \pm 15 \text { seconds }\end{array}$ \\
\hline
\end{tabular}

\section{Development Stage}

At the development stage, a video is made based on a design that the supervisor has approved. Tools and materials used to make learning videos, camera devices, microphones, green cloth, and tripods. The parts of the learning videos that have been made are as follows. The first is the opening, containing the identity of the learning video, which consists of the Undiksha logo, the identity of the author, the author's supervisor, the title of the author's research, learning objectives, greeting students, and linking the material with the environment around students. The second is the core material, presented by providing examples of problems, for example, comparing concrete objects around the student's environment to find out the results, which consist of less than, more than, or equal. An example of the first problem is to compare concrete objects as many as three oranges and five bananas to find out the results by looking for pairs between oranges and bananas. Next, an example of the second problem is to compare three balls and two hats to find out the result by finding a pair between the ball and the hat, so that the result is three balls more than two hats. Finally, an example of the third problem is to compare four pens and four erasers to find out the results by looking for pairs between a pen and an eraser so that four erasers are the same as four pens. The third is closing, reinforcing by providing an explanation using a number line, conclusions related to the learning that has been done, providing practice questions, and ending the learning. The display of counting learning videos, opening, core material, and closing, is presented in Table 5.

Table 5. The process of developing numeracy learning videos

Caption
The opening part of the numeracy learning video
Putu Andre Apriliawan 1711031272
PGSD FIP Undiksha




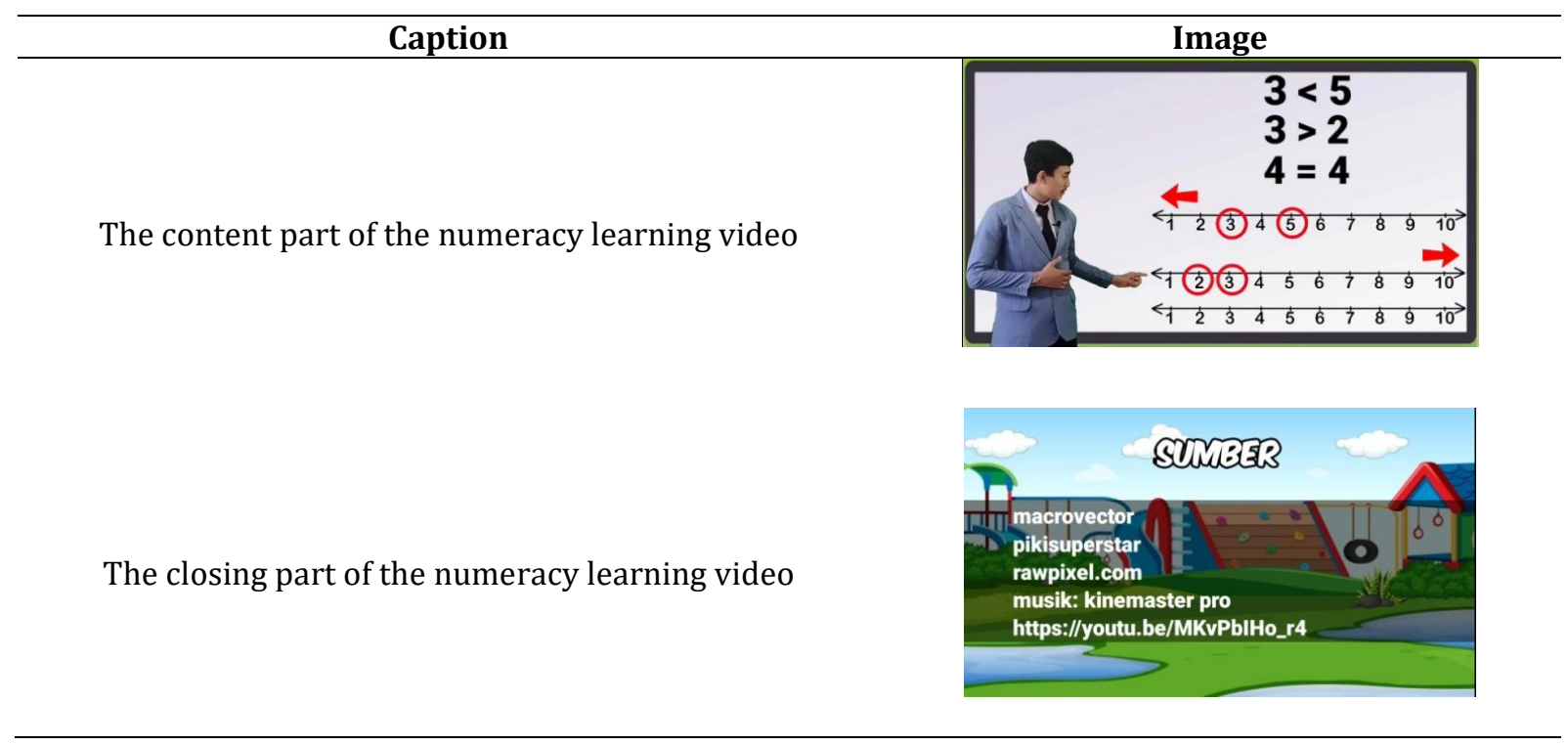

The analysis was carried out by calculating the average score obtained on the validation sheet by six experts. This score is then converted to a five-scale conversion guideline to determine the level of validity of the developed arithmetic learning video. The data on the validity of the counting learning videos are presented in Table 6 and Table 7.

Table 6. The average score of the validity of the numeracy learning video

\begin{tabular}{|c|c|c|c|}
\hline No & Rating points & Average & Criteria \\
\hline 1 & Material images can be seen clearly & 5,00 & Very good \\
\hline 2 & $\begin{array}{l}\text { Image size is appropriate for first graders of } \\
\text { elementary school }\end{array}$ & 4,75 & Very good \\
\hline 3 & $\begin{array}{l}\text { Selection of attractive colors, backgrounds, text, } \\
\text { images, and animations }\end{array}$ & 4,75 & Very good \\
\hline 4 & $\begin{array}{l}\text { The motion speed of the image is suitable for first } \\
\text { graders of elementary school }\end{array}$ & 4,75 & Very good \\
\hline 5 & Image lighting is correct & 4,75 & Very good \\
\hline 6 & The narrator's voice is clear and informative & 4,75 & Very good \\
\hline 7 & $\begin{array}{l}\text { The rhythm of the voice presented by the narrator is } \\
\text { according to the needs of first-grade elementary } \\
\text { school students (not too slow and not too fast) }\end{array}$ & 4,75 & Very good \\
\hline 8 & $\begin{array}{l}\text { The sound of the music matches the atmosphere and } \\
\text { the image display }\end{array}$ & 4,75 & Very good \\
\hline 9 & Easy-to-read text type & 4,75 & Very good \\
\hline 10 & $\begin{array}{l}\text { The text size is appropriate (not too small and not too } \\
\text { big) }\end{array}$ & 5,00 & Very good \\
\hline 11 & Display and presentation of interesting material & 5,00 & Very good \\
\hline 12 & $\begin{array}{l}\text { The duration setting is suitable for first-grade } \\
\text { elementary school students }\end{array}$ & 4,75 & Very good \\
\hline 13 & The presentation of the material has a clear storyline & 4,50 & Very good \\
\hline & Total & 4,78 & Very good \\
\hline
\end{tabular}

Table 7. The average score of the validity of the numeracy learning video material

\begin{tabular}{|c|c|c|c|}
\hline No & Rating points & Average & Criteria \\
\hline 1 & The material in the learning video is clear & 5,00 & Very good \\
\hline 2 & Learning objectives in learning videos & 5,00 & Very good \\
\hline 3 & Design & 5,00 & Very good \\
\hline 4 & $\begin{array}{l}\text { The learning material in the learning video is } \\
\text { appropriate }\end{array}$ & 5,00 & Very good \\
\hline 5 & In the learning video, the distribution and coherence of & 4,50 & Very good \\
\hline
\end{tabular}




\begin{tabular}{clcc}
\hline No & \multicolumn{1}{c}{ Rating points } & Average & Criteria \\
\hline 6 & $\begin{array}{l}\text { the material is correct } \\
\text { The language used in the learning video is following } \\
\text { the rules of the Indonesian language }\end{array}$ & 4,75 & Very good \\
7 & $\begin{array}{l}\text { The sentences used in the learning video are easy to } \\
\text { understand and understand }\end{array}$ & 5,00 & Very good \\
8 & $\begin{array}{l}\text { The language used in the learning video is already } \\
\text { communicative } \quad \text { Total }\end{array}$ & 4,75 & Very good \\
\end{tabular}

Table 6 and Table 7 show that the average score of all aspects of numeracy learning videos assessed when converted based on five-scale conversion guidelines is in the range of $3.75<\mathrm{X} 5.00$. It means that all aspects of the arithmetic learning video are considered to have very good qualifications. It is known that the average score of the overall numeracy learning video validation for learning videos is 4.78 , and the average material validation score is 4.87 . It means that the numeracy learning video developed is classified as very good based on expert judgment. This score is in the range of $3.75<\mathrm{X} 5.00$ with very good qualifications. Therefore, learning to count for grade I elementary school students is declared valid.

\section{Discussion}

The analysis of the average score of the validation of the arithmetic learning video for the learning video is 4.78 . The average score of the validation of the material is 4.87 . Then it is converted using a fivescale conversion guide in the range of $3.75<\mathrm{X} 5.00$. Therefore, the numeracy learning video for first-grade elementary school students is declared valid with very good qualifications. The developed media got very good qualification results. Aspects that are used as a reference in the assessment of numeracy learning videos have assessment points. Learning videos are good if they meet six aspects: visual aspects, audio aspects, typographic aspects, presentation aspects, material aspects, and linguistic aspects.

The first aspect, the visual aspect of the video learning to count, obtained an average result of 4.80 with very good qualifications based on the five scale conversion guidelines. The image size is appropriate for first-grade elementary school students. The speed of movement of the image is suitable for students in the first grade of elementary school. The selection of colors, backgrounds, texts, images, and animations is made attractive. The lighting of the images is clear. The material images can be seen clearly. The use of appropriate colors, backgrounds, and animations that attract students' interest in using video media is designed so that it is expected to improve students' numeracy skills. The visual aspect can facilitate understanding and strengthen memory by choosing the right background, color, and animation to attract students' interest, besides that it can also foster student interest and can provide a relationship between the content of the subject matter and the real world (Arsyad, 2014; Diputra, 2016; Mumtahabah, 2014; Somani \& Somani, 2021). The second aspect, the audio aspect of the numeracy learning video, obtained an average result of 4.75 with very good qualifications based on the five-scale conversion guidelines. Because the narrator's voice is clear and informative, the rhythm of the voice presented by the narrator is according to the needs of first-grade elementary school students (not too slow and not too fast), and the sound of the music matches the mood and the image display. The narrator's voice is not too fast and not too slow. It is important to do it because it is according to the characteristics of low-grade students who still need more understanding. Audio acts as a learning aid that students hear to get information to stimulate students' attention and thoughts in gaining knowledge, skills, or attitudes (Arsyad, 2014; Mumtahabah, 2014; Ratminingsih, 2016).

The third aspect is the typographical aspect of the numeracy learning video, which obtained an average result of 4.88 with very good qualifications based on five-scale conversion guidelines. The text size is appropriate (not too small and not too large), and the type of text is easy to be read. Typography is a visual description of verbal communication in letters, numbers, and punctuation by following the design and rules (Arsyad, 2014; Maulana, 2021; Purba, 2016). Typography is important to make it easier for children to obtain information in written form given in learning videos. The fourth aspect, the numeracy learning video presentation, obtained an average of 4.75 with very good qualifications based on five scale conversion guidelines. It is because the duration setting is suitable for first-grade elementary school students. The display and presentation of the material have an appeal, and the presentation of the material has a clear storyline. The effectiveness of the use of technical means in presentation depends not only on the proper determination of its place in the training system but also on how rationally the structure of the video lesson is organized, how the capabilities of the video are aligned with the learning objectives (Arsyad, 2014; Leyla \& Komila, 2021). 
The fifth aspect, the numeracy learning video material, obtained an average of 5.00 with very good qualifications based on the five scale conversion guidelines. In the learning video, the distribution and coherence of the material are correct, the material in the learning video is clear, the learning video is appropriate, and the learning objectives in the learning video are clear. The Suitability between the subject matter and the video presented will help students understand the material more easily to improve student learning outcomes (Arsyad, 2014; Park \& Kang, 2021). The sixth aspect, the linguistic aspect of the numeracy learning video, obtained an average of 4.75 with very good qualifications based on the five scale conversion guidelines. The level of language used in the learning video follows the cognitive abilities of first-grade elementary school students. The language used in video learning is communicative. The language used in the learning video follows the rules of the Indonesian language, and the sentences used in the learning video are easy to understand (Arsyad, 2014; Maulana, 2021). Based on this, it is known that the video learning counting for first-grade elementary school students that was developed is feasible to be used as a learning medium for elementary school students. These aspects have very good qualifications. The video learning counting is feasible to use in visual aspects, audio aspects, typographical aspects, presentation aspects, material aspects, and linguistic aspects.

This research produces a video of learning to count for first-grade elementary school students. The development of this media adapted to the situation, conditions, and needs in the field. This media is appropriate and able to overcome the problems resulting in this pandemic period the lack of learning media to support the learning process, especially counting videos for first-grade elementary school students. The use of learning media can attract the desire and motivation of students to learn. The learning media is packaged in a fun way and can attract students' attention without reducing the benefits of the learning media. Learning videos are a place to convey messages that can stimulate students' thoughts, feelings, attention, and curiosity, thus encouraging the learning process to occur from within according to learning objectives.

The research results obtained are in line with the research results conducted by (Syamsuddin \& Lukman, 2019) state that the level of validation of the developed numeracy learning media is quite good. It can be seen from the results of the t-test, by using the compact count media, students scored above 70 (91.67\%), which were classified as complete. Other research stated that the development of the resulting learning video was feasible to use (Purwanti, 2015). The next assessment stated that the numeracy learning video used was worth learning (Yuliani et al., 2017). It can be seen from the first assessment using learning videos by $65.43 \%$, and in the second learning, it increased to $84.18 \%$. It can be seen from the assessment of material design experts by $87.5 \%$ and learning video expert data by $82.5 \%$. The next research states that the resulting learning video is feasible. It can be seen from $100 \%, 60 \%$ stated complete and detailed information, and $40 \%$ responded very enthusiastically to the information in the video (Batubara \& Ariani, 2016). This research implies that students can learn to use media, especially counting videos, to assist in the learning process towards a more contextual direction. In addition, the teacher is helped in conveying numeracy material. During this pandemic, teachers must further develop their creativity in utilizing media for the learning process. Similar research is expected to develop learning videos with different materials and methods. The principal must also guide teachers to use media during this pandemic in the learning process, both direct coaching and through seminars or workshops to increase teacher creativity.

\section{CONCLUSION}

Based on the results of the research that has been carried out, it is known that the numeracy learning video for grade I elementary school students was developed through a validation and revision process with very good qualifications. Thus, the developed numeracy learning video can be used as an innovative learning medium by teachers and students in a more meaningful and fun learning process and is declared valid with very good qualifications and is worthy of learning.

\section{REFERENCES}

Agung, A. A. (2016). Statistik Dasar untuk Pendidikan. Depublish.

Annur, M. F. (2020). Analisis Kesulitan Mahasiswa Pendidikan Matematika Dalam Pembelajaran Daring Pada Masa Pandemi Covid-19. Jurnal Kajian, Pnelitian Dan Pengembangan Kependidikan, 11(2), 195-201. https://doi.org/10.31764/paedagoria.v11i2.2544.

Arsyad. (2014). Media Pembelajaran. PT. Raja Grafindo Persada.

Aunio, P., Korhonen, J., Ragpot, L., Törmänen, M., \& Henning, E. (2021). An early numeracy intervention for first-graders at risk for mathematical learning difficulties. Early Childhood Research Quarterly, 55, 
252-262. https://doi.org/10.1016/j.ecresq.2020.12.002.

Battistin, E., De Nadai, M., \& Vuri, D. (2017). Counting rotten apples: Student achievement and score manipulation in Italian elementary Schools. Journal of Econometrics, 200(2), 344-362. https: //doi.org/10.1016/j.jeconom.2017.06.015.

Batubara, H. H., \& Ariani, D. N. (2016). Pemanfaatan Video sebagai Media Pembelajaran Matematika SD/MI. Muallimuna: Jurnal Madrasah Ibtidaiyah, 47. https://doi.org/10.31602/muallimuna.v2i1.741.

Cahyadi, R. A. H. (2019). Pengembangan Bahan Ajar Berbasis Addie Model. Halaqa: Islamic Education Journal, 3(1), 35. https://doi.org/10.21070/halaqa.v3i1.2124.

Dewi, W. A. F. (2020). Dampak COVID-19 terhadap Implementasi Pembelajaran Daring di Sekolah Dasar. Edukatif: Jurnal Ilmu Pendidikan, 2(1), 55-61. https://doi.org/10.31004/edukatif.v2i1.89.

Dhir, S., Ramesh, S., \& Kaur, M. J. (2021). Online education amidst pernicious covid scourge: Altering traditional educational system and implementation of arts-friendly distance education strategies. Annals of the Romanian Society for Cell Biology, 7. Annals of the Romanian Society for Cell Biology, 25(4), 10336-10343. https://www.annalsofrscb.ro/index.php/journal/article/view/3796.

Diputra, K. S. (2016). Pengembangan Multimedia Pembelajaran Tematik Integratif Untuk Siswa Kelas IV Sekolah Dasar. JPI (Jurnal Pendidikan Indonesia), 5(2), 125. https://doi.org/10.23887/jpiundiksha.v5i2.8475.

Gayathri, B., Vedavyas, R., Sharanya, P., \& Karthik, K. (2021). Effectiveness of reflective learning in skillbased teaching among postgraduate anesthesia students: An outcome-based study using video annotation tool. Medical Journal Armed Forces India, 77, S202-S207. https: //doi.org/10.1016/j.mjafi.2020.12.028.

Hakim, A. R., \& Windayana, H. (2016). Pengaruh Penggunaan Multimedia Interaktif Dalam Pembelajaran Matematika Untuk Meningkatkan Hasil Belajar Siswa SD. EduHumaniora / Jurnal Pendidikan Dasar Kampus Cibiru, 4(2). https://doi.org/10.17509/eh.v4i2.2827.

Ilhami, R. S., \& Rimantho, D. (2017). Penilaian Kinerja Karyawan dengan Metode AHP dan Rating Scale. Jurnal Optimasi Sistem Industri, 16(2), 150. https://doi.org/10.25077/josi.v16.n2.p150-157.2017.

Komariah, I., \& Sundayana, R. (2017). Meningkatkan aktivitas belajar matematika siswa dengan menggunakan media domat. Mosharafa: Jurnal Pendidikan Matematika, 6(3), 323-332. https://doi.org/10.31980/mosharafa.v6i3.321.

Krishnan, A. G., Srisai Devikrishna, D., \& Aich, S. C. (2021). Online education amidst pernicious covid scourge: Altering traditional educational system and implementation of arts-friendly distance education strategies. Annals of the Romanian Society for Cell Biology, 25(4), 7470-7475. https: //www.annalsofrscb.ro/index.php/journal/article/view/3379.

Kurniawan, D. C., Kuswandi, D., \& Husna, A. (2018). Pengembangan Media Video Pembelajaran Pada Mata Pelajaran IPA Tentang Sifat Dan Perubahan Wujud Benda Kelas IV SDN Merjosari 5 Malang. Jinotep: Jurnal Inovasi Dan Teknologi Pembelajaran, 4(2). https://doi.org/10.17977/um031v4i22018p119.

Kurniawan, T. D., \& Trisharsiwi, T. (2016). Pengaruh Penggunaan Media Video Pembelajaran Terhadap Prestasi Belajar Ilmu Pengetahuan Sosial Siswa Kelas V SD Se-Kecamatan Gedangsari Gunungkidul Tahun Ajaran 2015/2016. Jurnal Pendidikan Ke-SD-An, 3(1), 21-26. https://doi.org/10.30738/trihayu.v3i1.739.

Kurniawan, Y. I., \& Rivaldi, M. F. (2021). Game Edukasi Pengenalan dan Pembelajaran Berhitung untuk Siswa Kelas 1 Sekolah Dasar. Jurnal Manajemen Informatika (JAMIKA), 11(1), 47-59. https://doi.org/10.34010/jamika.v11i1.4354.

Kusumaningrum, B., \& Wijayanto, Z. (2020). Apakah Pembelajaran Matematika Secara Daring Efektif? (Studi Kasus pada Pembelajaran Selama Masa Pandemi Covid-19). Kreano, Jurnal Matematika Kreatif-Inovatif, 11(2), 139-146. https://doi.org/10.15294/kreano.v11i2.25029.

Leyla, K., \& Komila, M. (2021). Communicative competense and ways to reach it in teaching foreign languages. Annals of the Romanian Society for Cell Biology, 25(1), 7098-7109. https://www.annalsofrscb.ro/index.php/journal/article/view/880.

Malapata, E., \& Wijayanigsih, L. (2019). Meningkatkan Kemampuan Berhitung Anak Usia 4-5 Tahun melalui Media Lumbung Hitung. Jurnal Obsesi : Jurnal Pendidikan Anak Usia Dini, 3(1), 283. https://doi.org/10.31004/obsesi.v3i1.183.

Manta, O. C., \& Enache, R. G. (2020). Online learning of socio-emotional behaviors in primary education during the COVID 19 pandemic. Case study. Technium Social Sciences Journal, 6, 92-98. https: //techniumscience.com/index.php/socialsciences/article/view/2662.

Mardika, T. (2019). Analisis Faktor-Faktor Kesulitan Membaca Menulis dan Berhitung Siswa Kelas 1 SD. Dinamika Jurnal Ilmiah Pendidikan Dasar, 10(1), 28-33. 
https://doi.org/10.30595/dinamika.v10i1.4049.

Maulana, A. (2021). Perancangan buku menggambar huruf dengan teknik grid untuk tipografer pemula. Jurnal Pendidikan Seni Rupa, 6(2), 9-15. https://doi.org/10.30738/cilpa.v6i2.9842.

Mumtahabah, N. (2014). Penggunaan Media Visual Dalam Pembelajaran PAI. Al Hikmah: Jurnal Studi Keislaman, 4(1), 91-104. https://doi.org/10.36835/hjsk.v4i1.511.

Mustaqim, I., \& Kurniawan, N. (2018). Pengembangan Media Pembelajaran Berbasis Augmented Reality. Lentera Pendidikan: Jurnal Ilmu Tarbiyah Dan Keguruan, 21(1), 59-72. https://doi.org/10.24252/lp.2018v21n1i6.

Nengrum, T. A., Pettasolong, N., \& Nuriman, M. (2021). Kelebihan dan Kekurangan Pembelajaran Luring dan Daring dalam Pencapaian Kompetensi Dasar Kurikulum Bahasa Arab di Madrasah Ibtidaiyah 2 Kabupaten Gorontalo. Jurnal Pendidikan, 30(1), 1-12. https://doi.org/https://doi.org/10.32585/jp.v30i1.1190.

Nurdin, E., Ma'aruf, A., Amir, Z., Risnawati, R., Noviarni, N., \& Azmi, M. P. (2019). Pemanfaatan video pembelajaran berbasis Geogebra untuk meningkatkan kemampuan pemahaman konsep matematis siswa SMK. Jurnal Riset Pendidikan Matematika, 6(1), 87-98. https://doi.org/10.21831/jrpm.v6i1.18421.

Pamungkas, S. A., Ihsanudin, Novaliyosi, \& Yandari, I. V. (2018). Video Pembelajaran Berbasis Sparkol Videoscribe: Inovasi pada Perkuliahan Sejarah Matematika. Prima: Jurnal Pendidikan Matematika, 2(2), 127-135. https://doi.org/10.31000/prima.v2i2.705.

Park, S. Y., \& Kang, S. J. (2021). The effects of maternity video education on learning motivation, learning achievement, learning immersion and major satisfaction. Annals of the Romanian Society for Cell Biology, 25(1), 878-882.

Prihatin, Y. (2017). Problematika Keterampilan Menyimak Dalam Pembelajaran Bahasa Indonesia. Sastranesia, 5(3), 45-52. https://core.ac.uk/download/pdf/267901046.pdf.

Purba, R. (2016). Tipografi Kreasi Motif Gorga Batak. PROPORSI: Jurnal Desain, Multimedia Dan Industri Kreatif, 1(2), 190-201. https://doi.org/10.22303/proporsi.1.2.2016.190-201.

Purwani, A., Fridani, L., \& Fahrurrozi. (2019). Pengembangan Media Grafis untuk Meningkatkan Siaga Bencana Banjir. Jurnal Obsesi: Jurnal Pendidikan Anak Usia Dini, 3(1), 55. https://doi.org/10.31004/obsesi.v3i1.142.

Purwanti, B. (2015). Pengembangan Media Video Pembelajaran Matematika dengan Model Assure. Jurnal Kebijakan Dan Pengembangan Pendidikan, 3(1), 42-47. https://doi.org/10.22219/jkpp.v3i1.2194.

Ramprathap, K. (2021). Using Social Media as an Learning Tool on Students ' Collaborative Learning Using SEM Model with the Reference to Engineering Students in Tamil Nadu. Annals of the Romanian $\begin{array}{lllll}\text { Society } & \text { for } & \text { Biology, 25(4), 9689-9694. }\end{array}$ http://annalsofrscb.ro/index.php/journal/article/view/3713.

Ratminingsih, N. M. (2016). Efektivitas Media Audio Pembelajaran Bahasa Inggris Berbasis Lagu Kreasi Di Kelas Lima Sekolah Dasar. JPI Uurnal Pendidikan Indonesia), 5(1), 27. https://doi.org/10.23887/jpi-undiksha.v5i1.8292.

Rigianti, H. A. (2020). Kendala Pembelajaran Daring Guru Sekolah Dasar Di Kabupaten Banjarnegara. Elementary School: Jurnal Pendidikan Dan Pembelajaran Ke-SD-An, 7(2), 297-302. https://doi.org/10.31316/esjurnal.v7i2.768.

Sadikin, A., \& Hamidah, A. (2020). Pembelajaran Daring di Tengah Wabah Covid-19. Biodik, 6(2), 109-119. https://doi.org/10.22437/bio.v6i2.9759.

Saiboon, I. M., Musni, N., Daud, N., Shamsuddin, N. S., Jaafar, M. J., Hamzah, F. A., \& Bakar, A. A. (2021). Effectiveness of Self-Directed Small-Group-Learning Against Self-Directed Individual-Learning Using Self-Instructional-Video in Performing Critical Emergency Procedures Among Medical Students in Malaysia: A Single-Blinded Randomized Controlled Study. Clinical Simulation in Nursing, 56, 46-56. https://doi.org/10.1016/j.ecns.2021.02.006.

Setiawan, R. H., \& Harta, I. (2014). Pengaruh Pendekatan Open-Ended Dan Pendekatan Kontekstual Terhadap Kemampuan Pemecahan Masalah Dan Sikap Siswa Terhadap Matematika. Jurnal Riset Pendidikan Matematika, 1(2), 241. https://doi.org/10.21831/jrpm.v1i2.2679.

Somani, P., \& Somani, N. (2021). Inform the Design of Indian Cinema Literature Inclusivity for People with Sensory Disabilities. Annals of the Romanian Society for Cell Biology, 25(6), 1290-1296. https://www.annalsofrscb.ro/index.php/journal/article/view/5613.

Syamsuddin, A., \& Lukman, A. (2019). Penggunaan Media Edukasi Hitung Kompak Dan dampaknya Terhadap Kemampuan Berhitung Siswa Sekolah Dasar. JRPD (Jurnal Riset Pendidikan Dasar), 2(1), 1-8. https://doi.org/10.26618/jrpd.v2i1.2052.

Tegeh, I. M., \& Kirna, I. M. (2013). Pengembangan Bahan Ajar Metode Penelitian Pendidikan Dengan Addie Model. Jurnal Ikatan Alumni (IKA) Universitas Pendidikan Ganesha, 11(1). 
https://doi.org/10.23887/ika.v11i1.1145.

Verdeflor, R. N., \& Pacadaljen, L. M. (2021). Outcomes of the course mathematics in the modern world: A phenomenological study. Annals of the Romanian Society for Cell Biology, 25(1), 2586-2599. https://www.annalsofrscb.ro/index.php/journal/article/view/370.

Villegas, V., Preiolo, S., Rocca, M., Ipince, A., \& Bakrania, S. (2020). Impacts of Health-Related School Closures on Child Protection Outcomes: A review of evidence from past pandemics and epidemics and lessons learned for COVID-19 Cirenia. Pharmacological Research, 104743. https://doi.org/10.1016/j.ijedudev.2021.102431.

Yatini, T., Ali, M., \& Yuniarni, D. (2013). Peningkatan kemampuan berhitung permulaan dengan menggunakan media gambar pada anak usia 5-6 tahun. Jurnal Pendidikan Dan Pembelajaran, 2(12), 1-18. https: //jurnal.untan.ac.id/index.php/jpdpb/article/view/3994.

Yuliani, D., Antara, P. A., \& Magta, M. (2017). Pengaruh Video Pembelajaran Terhadap Kemampuan Berhitung Permulaan Anak Kelompok B di Taman Kanak-Kanak. Pendidikan Anak Usia Dini Universitas Pendidikan Ganesha, 96-105. https://doi.org/http://dx.doi.org/10.23887/paud.v5i1.11309.

Yunita, D., \& Wijayanti, A. (2017). Pengaruh Media Video Pembelajaran Terhadap Hasil Belajar IPA Ditinjau Dari Keaktifan Siswa. SOSIOHUMANIORA: Jurnal Ilmiah Ilmu Sosial Dan Humaniora, 3(2), 153-160. https://doi.org/10.30738/sosio.v3i2.1614. 